\title{
Rethinking the economic possibilities of our grandchildren: what is the future of consumption?
}

\author{
Andreas Chai ${ }^{1}$ (D)
}

Published online: 10 March 2017

(C) Springer-Verlag Berlin Heidelberg 2017

\section{Introduction}

In the "Economic Possibilities of our Grandchildren" (Keynes 1933), John Maynard Keynes recognized that the extent to which economic growth delivers better living conditions in the long run is mediated by how the character of demand evolves as households become more affluent. If consumer needs are indeed insatiable, there is little reason to doubt that any extra income generated by economic growth will continuously be converted into increases in demand ad infinitum (Stiglitz 2008). This is the position adopted by much of the growth literature that typically does not consider the possibility of non-homothetic preferences. In contrast, Keynes started to outline a more nuanced approach in this essay. In line with other scholars preceding him (e.g. Menger 1871) Keynes considered the nature of the underlying needs that motivate consumption and how rising affluence may impact their satisfaction. He conjectured that there are two types of needs: absolute and relative needs. Absolute needs are satiable and Keynes argued that within a hundred years, these needs would be sufficiently satisfied to the extent that further energies could be devoted to non-economic purposes (Keynes 1933; Pecchi and Piga 2008). However, relative needs are insatiable because their satisfaction is linked to a desire for superiority over others. Thus, the character of the needs that are the ultimate ends of economics activity must be taken into account in order to take proper stock of the extent to which long run economic growth translates into rising human welfare. Moreover, the possibility that the economy has shifted from satisfying absolute needs towards satisfying relative needs also raises deeper questions concerning the extent to which further increases in per capita consumption levels are desirable (Easterlin 2001; Frank 2001; Van den Bergh 2011) and what behavioural processes and social institutions are responsible for shaping the evolving character of demand (Scitovsky 1976; Pasinetti 1981; Bowles 1998; Witt 2001; Bisin and Verdier 2001; Earl and Potts 2004).

Andreas Chai

a.chai@griffith.edu.au

1 Griffith Business School, Gold Coast Campus, Griffith University, Southport, Qld 4222, Australia 
The purpose of this special issue is to reconsider the coevolving relationship between income and the character of household consumption patterns and its implications of the economy, as well as society at large. Will per capita consumption expenditures always continue to grow in the same manner as it has in the previous two centuries? There is little doubt that current, resource-intensive consumption patterns in the developed world are setting important trends for an emerging class of affluent consumers in developing countries. Given that by 2030 around 3.1 billion people are projected to enter the middle class around the word (OECD 2010), questions arise about how sustainable these shifts in global consumption patterns are. At the same time, consumption patterns in the West are also being fundamentally reshaped as consumers, thanks to rising real incomes and technological progress, have well and truly moved beyond satisfying their basic needs. Here, the nature of the economic problem is increasingly focused on more non-material and abstract aspects of life such as social interactions, the allocation of time and other cognitive concerns, as well as the avoidance of boredom (Bianchi 2002).

The time is rife to consider the implications of these global trends as a renaissance is currently underway in the contemporary study of demand and consumer behaviour. In microeconomics, the role of the social environment has become a prominent issue (e.g., Frank 1997; Hopkins and Kornienko 2004; Arrow and Dasgupta 2009). There is also a shift towards considering how biological evolution shapes consumption patterns (Witt 2001; Robson and Kaplan 2003; Rayo and Becker 2007; Frank 2012). In macroeconomics, there is a growing awareness of the role that income inequality plays in shaping consumer demand (Bertola et al. 2014).

These new research perspectives have created the impetus to reconsider longstanding questions in micro- and macroeconomics that are still largely unanswered. For example, do consumers have an insatiable appetite for novel goods and services, and if so, to what extent is the insatiable nature of consumer demand co-determined by the influence of social institutions? Apart from Engel's law, what other empirical regularities exist in the manner in which consumption patterns change under the influence of a growing per capita income? How do these changes transform the structure of growing economies? If consumption growth is to some extent endogenously influenced by economic and social processes, what possibilities are there for inducing consumers to adopt sustainable consumption patterns?

\section{Summary of contributions}

This special issue features contributions that seek to address some of these new questions. The first two contributions analyse Keynes' sketch of long run economic growth by focusing on the role that institutions play in mediating the relationship between economic growth and realizing higher living standards. Friedman (this issue) notes how technological advances have contributed to rising income inequality in the U.S. and the growing share of income earned by capital. He argues that these two reasons may explain why rising labour productivity does not automatically translate into higher living standards for all. He argues the case for renewed investment in public goods that stand to benefit everyone and thereby help blunt the aggregate and distributional effects of technological progress on the economy. Potts (2017) argues 
that the key missing feature of Keynes' brief sketch of long run growth is failure to recognize that both supply and demand conditions in the economy are critically influenced by economic institutions. Institutional evolution not only shapes how a given set of resources can be used to solve the economic problem but also the very character of the economic problem as such. Given a change in institutional configuration, the composition of demand will also change. This occurs because institutions do not evolve in a cumulative fashion but rather via creative destruction through which new production technologies replace existing technologies and new types of demand replace old types of demand.

The next two papers contribute to building a behavioral account of the way in which consumption patterns expand and adapt to rising household income \& evolving institutional conditions. Chai (2017) reviews a number of historical case study and empirical investigations conducted over the last 15 years that employ Witt's (2001) "Learning to Consume' (LTC) approach to study long run trends in household consumption patterns. The study shows how this body of work has delivered insights into the precise manner in which the character of demand is endogenously influenced by economic institutions and the implications for achieving sustainable levels of consumption. Witt (this issue) expands on this approach to tackle the important relationship between consumers' welfare and their levels of consumption. With this contribution, Witt challenges the view that raising the household's capacity to consume more can always be equated with higher household living standards.

One salient product of the LTC approach is a new empirical effort to studying consumption patterns. Where much of the literature on applied demand analysis models consumption behaviour as function of income and relative prices, LTC-inspired approaches use the concept of demand satiation and evolving preferences to study both the non-homothetic and intertemporal properties of consumer demand and how new innovations may disrupt existing income-consumption patterns. Bruns and Moneta (2017) use German household expenditure data to study how innovations and socioeconomic regimes influence the evolution of Engel Curves. Given that the rate of product innovations appears to be accelerating in markets related to the need for social recognition and novelty, Cooper (this issue) develops a model that considers the welfare effects of fashion cycles. The author explores how the rapid adoption of new goods could render consumer worse off through environmental externalities, losses in status, and rising preference inconsistencies.

The next two papers discuss the macroeconomic implications of income inequality in the presence of non-homothetic preferences. Saviotti and Pyka (this issue) develop a macroeconomic model which accounts for previous empirical finding suggesting that demand satiation in certain sectors is relatively unstable (e.g. Moneta and Chai 2014; Bruns and Moneta 2017). Their model highlights how entrepreneurial effort and the structure of the social environment may create the conditions in which it possible for industries to avoid a long term slowdown of the growth of demand. Foellmi and Zweimüller (2017) show how income inequality can have important consequences for growth by changing R\&D incentives. They highlight how inequality can have two distinct effects on R\&D activity if non-homothetic preferences exist. On the one hand, greater income inequality may generate a greater number of rich consumers who possess a higher willingness to pay for new goods and can thus fuel R\&D activities in certain sectors. On the other hand, the profitability of the resulting new goods related 
to these R\&D activities may be negatively affected by income inequality that reduces the size of the market for new goods.

\section{Conclusions}

Taken together, these contributions point towards two broad important methodological trends in contemporary economic thinking. First, a growing number of scholars are coming to accept that consumer preferences cannot be considered to be exogenous and stable in the long run. Consumer preferences are increasingly being seen as shaped in particular ways by rising affluence and institutional environments. The typically rather strict separation between demand and supply factors of economic growth becomes increasingly blurred (Mokyr 2000; De Vries 2008; McCloskey 2010). Second, demand analysis is becoming increasingly interdisciplinary in nature as a growing numbers of scholars identify and pursue new scientific arbitrage opportunities by introducing new insights from psychology and biology to account for consumer preferences and their long run evolution. This provides an exciting new basis for analyzing consumer welfare and precisely identifying the condition under which rising income generates increases in this welfare.

Acknowledgements The guest editor of this special issue would like to thank Ulrich Witt and Uwe Cantner. Several of the papers in this special issue were presented at the 2014 International Schumpeter Society conference in Jena, Germany. We thank all referees involved in the review process.

\section{Compliance with ethical standards}

Conflict of interest The authors declare that they have no conflict of interest.

\section{References}

Arrow KJ, Dasgupta PS (2009) Conspicuous consumption, inconspicuous leisure. Econ J 119(541):F497F516

Bertola G, Foellmi R, Zweimüller J (2014) Income distribution in macroeconomic models. Princeton University Press, Princeton

Bianchi M (2002) Novelty, preferences, and fashion: when goods are unsettling. J Econ Behav Organ 47(1):118

Bisin A, Verdier T (2001) The economics of cultural transmission and the dynamics of preferences. J Econ Theory 97(2):298-319

Bowles S (1998) Endogenous preferences: the cultural consequences of markets and other economic institutions. J Econ Lit 36(1):75-111

Bruns S, Moneta A (2017) Intertemporal propensity to consume. J Evol Econ doi:10.1007/s00191-016-0460-X

Chai A (2017) Tackling Keynes question: a look back on 15 years of 'learning to consume. J Evol Econ doi:10.1007/s00191-016-0455-7

Clark AE, Frijters P, Shields MA (2008) Relative income, happiness, and utility: an explanation for the Easterlin paradox and other puzzles. J Econ Lit 46(1):95-144

Cooper $\mathrm{K}$ (this issue) Consumer well-being in a future of accelerating novelty, $\mathrm{J}$ Evol Econ

De Vries J (2008) The industrious revolution: consumer behavior and the household economy, 1650 to the present. Cambridge University Press, New York 
Earl PE, Potts J (2004) The market for preferences. Camb J Econ 28(4):619-633

Easterlin RA (2001) Income and happiness: towards a unified theory. Econ J 111(473):465-484

Foellmi R, Zweimüller J (2017) Is Inequality harmful for innovation and growth? price versus market size effect. J Evol Econ doi:10.1007/s00191-016-0451-y

Frank RH (1997) The frame of reference as a public good. Econ J 107(445):1832-1847

Frank RH (2001) Luxury fever: why money fails to satisfy in an era of excess. Simon and Schuster, New York Frank RH (2012) The Darwin economy. Princeton University Press, New Haven

Friedman B (this issue) Work and consumption in an era of unbalanced technological change. J Evol Econ Hopkins E, Kornienko T (2004) Running to keep in the same place: consumer choice as a game of status. Am Econ Rev 94(4):1085-1107

Keynes JM (2010) Economic possibilities for our grandchildren. In Essays in Persuasion. Palgrave Macmillan UK. p 321-332

Menger C (1871) Principles of economics. The Free Press: Glencoe, Illinois

McCloskey DN (2010) Bourgeois dignity: why economics can't explain the modern world. University of Chicago Press, Chicago

Mokyr J (2000) Why “more work for mother?" Knowledge and household behavior, 1870-1945. J Econ Hist 60(1): $1-41$

Moneta A, Chai A (2014) The evolution of Engel curves and its implications for structural change theory. Camb J Econ 38(4):895-923

Organisation for Economic Cooperation and Development (OECD) (2010) The emerging middle class in developing nations. OECD Publications, Paris

Pasinetti LL (1981) Structural Change and Economic Growth. Cambridge, UK: Cambridge University Press

Pecchi L, Piga G (Eds) (2008) Revisiting Keynes: economic possibilities for our grandchildren. MIT Press

Potts J (2017) Institutions hold consumption on a leash: an evolutionary economic approach to the future of consumption J Evol Econ. doi:10.1007/s00191-015-0437-1

Rayo L, Becker GS (2007) Habits, peers, and happiness: an evolutionary perspective. Am Econ Rev 97(2): 487-491

Robson AJ, Hillard SK (2003) The evolution of human life expectancy and intelligence in hunter-gatherer economies. Am Econ Rev :150-169

Saviotti PP, Pyka A (this issue) Innovations, structural change and demand evolution: does demand saturate? J Evol Econ

Scitovsky T (1976) Joyless economy. Oxford University Press, Oxford

Stiglitz JE (2008) Toward a general theory of consumerism: reflections on Keynes's Economic possibilities for our grandchildren. In: Pecchi L, Piga G (eds) Revisiting Keynes: economic possibilities for our grandchildren, $\mathrm{p} 41-86$

Van den Bergh JC (2011) Environment versus growth—A criticism of "degrowth" and a plea for "a-growth". Ecol Econ 70(5):881-890

Witt U (2001) Learning to consume-A theory of wants and the growth of demand. J Evol Econ 11(1):23-36

Witt $U$ (this issue) The evolution of consumption and its welfare effects. J Evol Econ 